\title{
INTERPRETATION OF THE "PARETIC CURVE" IN LANGE'S COLLOIDAL GOLD TEST *
}

\section{LLOYD JAMES THOMPSON, M.D.}

Resident Physician, Massachusetts State Psychiatric Institute; Assistant in Psychiatry, Harvard Medical School

BOSTON

The occasional occurrence of a paretic gold curve in cases that were not paresis, and the occasional diagnosis of paresis without a paretic gold curve suggested that a closer study of this particular colloidal gold reaction should be made. A review of the rather extensive literature that has grown up since Lange ${ }^{1}$ first introduced this test in 1912 shows that various conclusions have been drawn concerning the value of the paretic curve. These conclusions, however, were based on a more or less limited number of cases.

At this hospital about 8,400 colloidal gold tests have been made on about 7,100 different cerebrospinal fluids. Of this number, 677 fluids gave paretic curves, and these constitute the basis for this study. A large majority of the patients coming to this hospital are in the early stages of their disease, and consequently these findings are those of the early stages, and are, therefore, the more valuable. Another advantage is that in almost every instance a fluid is obtained before antisyphilitic treatment is started. The diagnoses of all the cases considered have been confirmed by a long period of observation at this or some other state hospital, and in addition many have been confirmed by necropsy.

The preparation of the colloidal gold, the technic of the test, and the reading of the results have all been adequately described by many writers ${ }^{2}$ these points will, therefore, not be taken up in this article. I shall consider only the interpretation of the paretic gold curve.

* From the Massachusetts State Psychiatric Institute, Boston.

1. Lange: Ueber die Ausflockung von Gold Sol durch Liquor Cerebrospinalis, Berl. klin. Wchnschr. 49:897, 1912,

2. Lange: Ueber die Ausflockung von Gold Sol durch Liquor Cerebrospinalis, Berl. klin. Wchnschr. 49:897, 1912. Kaplan: Serology of Nervous and Mental Diseases, Philadelphia, W. B. Saunders Company, 1914. Miller, Brush, Hammes and Felton: A Further Study of the Diagnostic Value of the Colloidal Gold Reaction Together with a Method for the Preparation of the Reagent, Bull. Johns Hopkins Hosp. 26:391, 1915. Warwick and Nixon: A Study of the Colloidal Gold Reaction and Its Clinical Interpretation, Arch. Int. Med. 25:119 (Feb.) 1920. Lowrey: Cerebrospinal Fluids, Especially the Gold Reaction in Psychiatric Diagnosis, J. Nerv. \& Ment. Dis. 46:186 (Sept.) 1917. 
First, what shall be called a paretic curve? It is agreed that the typical paretic curve gives the following reading: $5555543100,^{3}$ but there are many variations that may still be called paretic curves. The number of tubes showing complete precipitation may be increased or decreased somewhat without altering the interpretation. In one case of undoubted paresis after an acute exacerbation and after some intraspinal treatment, all the usual ten tubes were reduced to fives with a sudden drop to the normal color in further dilutions. This case had previously given typical paretic curves, and soon after the typical curve reappeared. It also seems from experience with other cases that the number of fives may be reduced to two or three and the result may still be called a paretic curve if the general form of the typical curve is present. A reading such as 4444432100 should certainly be called a paretic curve, especially when the fours are well marked. However, if the reading starts with only threes, we are on the borderline between the paretic and the syphilitic curve. Therefore, if the general conformation of the typical paretic curve is present, and the reduction in the first three or more tubes is well marked in the fours or is in the fives, we may consider it a paretic curve. An irregular reading, such as 4525231000 , may be found after intensive treatment, as a result of poor gold solution or in contaminated fluids, and such a reading should always be questioned.

\section{GENERAL CONSIDERATIONS}

Because of the name, "paretic curve," the question is often asked, "Does a paretic curve always mean paresis?" or in other words, "Is it pathognomonic of paresis?" This question has been answered in the negative by many previous writers. Of this series of 677 paretic curves, thirty-nine cases were not paretic; of these fourteen were not cases of neurosyphilis (Table 1).

\section{PARETIC CURVES IN PARESIS}

Another question often asked is whether or not the fluids from cases of paresis always give paretic curves. This can also be answered in the negative by the fact that of 638 cases of paresis, a paretic curve was not found in the first fluid tested in eleven cases. However, four of these later developed a typical curve, and in the remainder only one specimen of spinal fluid was examined.

Among the cases of paresis just mentioned are included the cases diagnosed as taboparesis and juvenile paresis. These types gave typical results in every instance but two. A few other cases were found in

3. Solomon, Koefod and Welles: The Diagnostic Value of Lange's Gold Sol Test, Boston M. \& S. J. 173:957, 1915. 
table 1.-General Distribution of Paretic Curves

\begin{tabular}{|c|c|c|c|c|c|c|c|}
\hline \multirow[t]{2}{*}{ Author } & \multirow{2}{*}{$\begin{array}{c}\text { Number } \\
\text { of } \\
\text { Paretic } \\
\text { Curves }\end{array}$} & \multicolumn{2}{|c|}{ In Paresis } & \multicolumn{2}{|c|}{$\begin{array}{l}\text { Cerebrospinal } \\
\text { Syphilis or } \\
\text { Tabes }\end{array}$} & \multicolumn{2}{|c|}{$\begin{array}{c}\text { In Diseases } \\
\text { Other Than } \\
\text { Neurosyphilis }\end{array}$} \\
\hline & & $\underset{\text { ber }}{\text { Num- }}$ & $\begin{array}{c}\text { Per- } \\
\text { centage }\end{array}$ & $\underset{\text { ber }}{\text { Num- }}$ & $\begin{array}{c}\text { Per- } \\
\text { centage }\end{array}$ & $\underset{\text { ber }}{\text { Num- }}$ & $\begin{array}{c}\text { Per- } \\
\text { centage }\end{array}$ \\
\hline 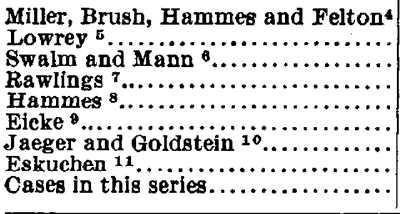 & $\begin{array}{r}151 \\
69 \\
62 \\
102 \\
52 \\
50 \\
48 \\
18 \\
677\end{array}$ & $\begin{array}{r}129 \\
65 \\
62 \\
101 \\
42 \\
50 \\
33 \\
17 \\
638\end{array}$ & $\begin{array}{r}85.4 \\
93.6 \\
100.0 \\
99.0 \\
80.7 \\
100.0 \\
68.7 \\
94.4 \\
94.2\end{array}$ & $\begin{array}{r}19 \\
3 \\
0 \\
0 \\
9 \\
0 \\
12 \\
1 \\
25\end{array}$ & $\begin{array}{r}12.5 \\
4.3 \\
0.0 \\
0.0 \\
17.3 \\
0.0 \\
25.0 \\
5.6 \\
3.7\end{array}$ & $\begin{array}{r}3 \\
1 \\
0 \\
1 \\
1 \\
0 \\
3 \\
0 \\
14\end{array}$ & $\begin{array}{l}2.1 \\
2.1 \\
0.0 \\
1.0 \\
2.0 \\
0.0 \\
6.3 \\
0.0 \\
2.1\end{array}$ \\
\hline
\end{tabular}

4. Miller, Brush, Hammes and Felton (Footnote 2).

5. Lowrey (Footnote 2).

6. Swalm and Mann: New York M. J. 101:719, 1915.

7. Rawlings: The Colloidal Gold Reaction in Four Hundred and NinetyEight Psychiatric Cases, Arch. Neurol. \& Psychiat. 2:180 (Aug.) 1919.

8. Hammes: The Comparative Value of the Wassermann, the Colloidal Gold and Other Spinal Fluid Tests, Am. J. M. Sc. 154:625 (Nov.) 1917.

9. Eicke: Die gold reaktion im liquor cerebrospinalis, München. med. Wchnschr. 60:2713, 1913.

10. Jaeger and Goldstein: Goldsolreaktion im liquor cerebrospinalis, Ztschr. f. d. ges. Neurol. u. Psychiat. O. 16:219, 1913.

11. Eskuchen: Die fünfte reaktion, Ztschr. f. d. ges. Neurol. \& Psychiat. O. $25: 486,1914$.

Table 2.-Cases of Paresis Without a Paretic Curve in the First Fluid Tested

\begin{tabular}{|c|c|c|c|c|c|c|c|c|}
\hline \multirow{2}{*}{$\underset{\text { ber }}{\text { Num- }}$} & \multirow{2}{*}{ Date } & \multirow{2}{*}{$\begin{array}{l}\text { Collojdal } \\
\text { Gold } \\
\text { Curve }\end{array}$} & \multirow{2}{*}{$\begin{array}{l}\text { Glu- } \\
\cos \theta\end{array}$} & \multirow{2}{*}{$\underset{\text { min }}{\text { Albu- }}$} & \multirow{2}{*}{ Cell } & \multicolumn{2}{|c|}{$\begin{array}{c}\text { Wassermann } \\
\text { Test }\end{array}$} & \multirow{2}{*}{ Remarks } \\
\hline & & & & & & $\begin{array}{c}\text { Cerebro- } \\
\text { spinal } \\
\text { Fluid }\end{array}$ & Serum & \\
\hline \multirow[t]{2}{*}{6941} & $6 / 24 / 16$ & 0001232100 & 3 & 3 & 58 & $55000^{*}$ & Posi- & Taboparesis, On ad- \\
\hline & $7 / 25 / 16$ & 5555533000 & 3 & 3 & 24 & 55500 & $\begin{array}{c}\text { Posi- } \\
\text { tive }\end{array}$ & $\begin{array}{l}\text { cal symptoms of } \\
\text { paresis }\end{array}$ \\
\hline \multirow[t]{2}{*}{11514} & $10 / 29 / 18$ & 2223310000 & 0 & $\mathbf{N}$ & $\mathbf{0}$ & $\begin{array}{l}\text { Posi- } \\
\text { tive }\end{array}$ & $\begin{array}{l}\text { Nega- } \\
\text { tive }\end{array}$ & $\begin{array}{l}\text { Diagnosis of paresis } \\
\text { recently conflrmed by }\end{array}$ \\
\hline & $11 / 12 / 18$ & 5554443310 & $\mathbf{0}$ & 1 & 1 & $\begin{array}{l}\text { Posi- } \\
\text { tive }\end{array}$ & $\begin{array}{l}\text { Posi- } \\
\text { tive }\end{array}$ & necropsy \\
\hline 4303 & $11 / 17 / 15$ & 3333210000 & 2 & 2 & 55 & $\begin{array}{l}\text { Doubt- } \\
\text { ful }\end{array}$ & $\begin{array}{l}\text { Posi- } \\
\text { tive }\end{array}$ & $\begin{array}{l}\text { Typical paretic symp- } \\
\text { toms }\end{array}$ \\
\hline 9217 & $8 / 16 / 16$ & 3333211000 & 1 & 1 & 27 & $\begin{array}{l}\text { Posi- } \\
\text { tive }\end{array}$ & $\begin{array}{l}\text { Posi- } \\
\text { tive }\end{array}$ & $\begin{array}{l}\text { Cause of death, general } \\
\text { paralysis }\end{array}$ \\
\hline 12036 & $1 / 27 / 19$ & 0004521000 & 1 & 1 & 2 & $\begin{array}{l}\text { Posi- } \\
\text { tive }\end{array}$ & $\begin{array}{l}\text { Posi- } \\
\text { tive }\end{array}$ & $\begin{array}{l}\text { Cause of death, general } \\
\text { paralysis }\end{array}$ \\
\hline \multirow[t]{3}{*}{11123} & $8 / 10 / 18$ & 1112321000 & 2 & 2 & 116 & 50000 & $\begin{array}{l}\text { Posi- } \\
\text { tive }\end{array}$ & $\begin{array}{l}\text { Diagnosis taboparesis; } \\
\text { treated since first L.P. }\end{array}$ \\
\hline & $12 / 2 / 18$ & 5554443221 & 1 & 1 & 2 & 555540 & $\begin{array}{l}\text { Posi- } \\
\text { tive }\end{array}$ & \\
\hline & $11 / 2 / 19$ & 5555443100 & 1 & 1 & 2 & 555550 & $\begin{array}{l}\text { Posi- } \\
\text { tive }\end{array}$ & \\
\hline 9496 & $10 / 14 / 17$ & 3332100000 & $\mathbf{3}$ & 3 & 27 & $\begin{array}{l}\text { Posi- } \\
\text { tive }\end{array}$ & $\begin{array}{l}\text { Posi- } \\
\text { tive }\end{array}$ & $\begin{array}{l}\text { Diagnosis confirmed at } \\
\text { Taunton State Hosp. }\end{array}$ \\
\hline 11981 & $1 / 17 / 19$ & 0001131100 & 1 & 2 & 17 & $\begin{array}{l}\text { Posi- } \\
\text { tive }\end{array}$ & $\begin{array}{l}\text { Posi- } \\
\text { tive }\end{array}$ & $\begin{array}{l}\text { Diagnosis confirmed at } \\
\text { Westboro State Hosp. }\end{array}$ \\
\hline 9244 & $8 / 21 / 17$ & 3333210000 & $\mathbf{1}$ & 1 & 46 & $\begin{array}{l}\text { Posi- } \\
\text { tive }\end{array}$ & $\begin{array}{l}\text { Posi- } \\
\text { tive }\end{array}$ & $\begin{array}{l}\text { Diagnosis confirmed at } \\
\text { Taunton State Hosp. }\end{array}$ \\
\hline 8520 & $4 / 18 / 17$ & 1132210000 & $\mathbf{0}$ & 2 & 38 & $\begin{array}{l}\text { Posi- } \\
\text { tive }\end{array}$ & $\begin{array}{l}\text { Posi- } \\
\text { tive }\end{array}$ & Typical paretic \\
\hline \multirow[t]{3}{*}{7788} & $12 / 6 / 16$ & 2221000006 & 3 & 4 & 59 & 55555 & $\begin{array}{l}\text { Posi- } \\
\text { tive }\end{array}$ & Treated after first L.P. \\
\hline & $12 / 23 / 16$ & 5555443300 & 3 & 3 & 40 & 50000 & Posi- & \\
\hline & $1 / 24 / 17$ & 1112310000 & 3 & 4 & 23 & 55555 & $\begin{array}{l}\text { Posi- } \\
\text { tive }\end{array}$ & . \\
\hline
\end{tabular}

* The reaction is recorded in various dilutions of spinal fluid from 2 e.c. to 0.1 c.c. The figure 5 means a strongly positive reaction. 
which there was not a paretic type of curve, but all of the patients had received previous intensive treatment before they were examined at this hospital.

The objection may be made that few cases were diagnosed as paresis in the absence of a paretic curve. That is the tendency, but it was found that many cases were diagnosed as paresis without a paretic curve; most of them, however, were later proved to be incorrectly diagnosed. One case, for instance, was consistently diagnosed as general paralysis in spite of the absence of a paretic curve in several fluids tested, but at necropsy no evidence, either microscopic or macroscopic, could be found to support this diagnosis.

TABLE 3.-Paretic Curves in Paresis

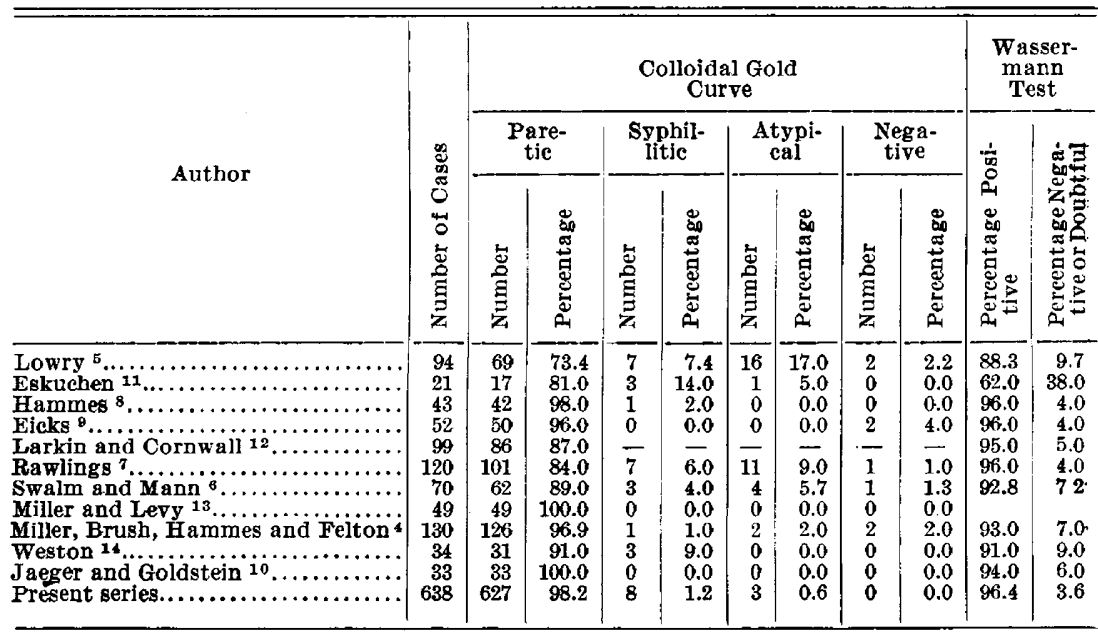

12. Larkin and Cornwall: Value of Laboratory Diagnosis in Neurosyphilis, Am. J. Syphilis 3:76, 1919.

13. Miller and Levy: Colloidal Gold Reactions in the Cerebrospinal Fluid Bull. Johns Hopkins Hosp. 25:133, 1915.

14. Weston: Colloidal Gold and Other Tests Applied to the Spinal Fluid, Am. J. Insan. 71:773, 1914.

\section{PARETIC CURVES IN OTHER DISEASES}

Cerebrospinal or Diffuse Neurosyphilis.-The differentiation of cerebrospinal syphilis from paresis is difficult, especially in the early stages, and apparently the colloidal gold test is not to be relied on entirely when such a question arises. In cerebrospinal syphilis the syphilitic type of curve (1233210000 or 3332110000) is most often found. However, in the series of cerebrospinal syphilis cases at this hospital several paretic curves were found in the first fluid examined, and some fluids developed a paretic reaction later. No case of this type was considered unless it was so typical that paresis could be 
excluded entirely. Of thirty-one cases of cerebrospinal syphilis, fifteen gave a paretic curve in the first fluid tested and six gave syphilitic curves; in four the colloidal gold curve was negative, and the remaining six gave atypical readings. - Of the fifteen cases with paretic curves, all but three showed marked psychotic symptoms, while those with the milder reaction showed chiefly physic symptoms, such as cranial nerve palsies, and the mental symptoms were mort or less in the background or entirely absent. ' In this type of neurosyphilis there may be parenchymatous involvement or simply meningitic and vascular changes. It would seem, therefore, from these findings that the paretic curve in cerebrospinal syphilis would indicate parenchymatous involvement.

TABle 4.-Colloidal Gold Tests in Cerebrospinal Syphilis

\begin{tabular}{|c|c|c|c|c|c|c|}
\hline Author & $\begin{array}{l}\text { Number } \\
\text { of Cases }\end{array}$ & $\begin{array}{l}\text { Paretic } \\
\text { Curves }\end{array}$ & $\begin{array}{c}\text { Syphilitic } \\
\text { Curves }\end{array}$ & $\begin{array}{c}\text { Chronic } \\
\text { Type }\end{array}$ & $\begin{array}{c}\text { Atypical } \\
\text { Curves }\end{array}$ & $\begin{array}{c}\text { Nega- } \\
\text { tive }\end{array}$ \\
\hline 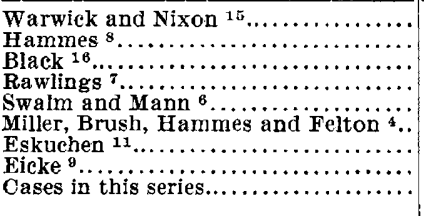 & $\begin{array}{l}26 \\
27 \\
39 \\
59 \\
10 \\
15 \\
13 \\
25 \\
31\end{array}$ & $\begin{array}{r}3 \\
3 \\
1 \\
1 \\
0 \\
4 \\
1 \\
0 \\
15\end{array}$ & $\begin{array}{r}10 \\
23 \\
15 \\
33 \\
6 \\
9 \\
12 \\
24 \\
6\end{array}$ & $\begin{array}{l}\ddot{Z} \\
\ddot{2} \\
= \\
=\end{array}$ & $\frac{9}{14}$ & $\begin{array}{l}4 \\
0 \\
3 \\
3 \\
4 \\
2 \\
1 \\
4\end{array}$ \\
\hline
\end{tabular}

15. Warwick and Nixon (Footnote 2).

16. Black, J. H.; Rosenberg, L., and McBride, R. B.: The Colloidal Gold Test, J. A. M. A. 69:1855 (Dec. 1) 1917.

Tabes Dorsalis.-In tabes, the colloidal gold reaction is generally of the $0123321100^{3}$ type and either this reaction or a negative result was obtained in most of the cases. However, two cases gave a paretic curve with the first lumbar puncture fluid and before any treatment was given. One other case of tabes developed a paretic curve under treatment. These cases have been under observation for two years or more and have not shown any mental symptoms.

Undifferentiated Neurosyphilis.-The cases of undifferentiated neurosyphilis are those that show no clinical signs for differentiation and yet give a positive Wassermann reaction and other findings in the cerebrospinal fluid. A group of such cases has been described by Southard and Solomon ${ }^{17}$ under the term "paresis sine paresi." In this series of paretic curves appear the curves of seven patients with neurosyphilis who have been under observation for some time and yet have not shown any physical or mental symptoms that would warrant a diagnosis of either paresis or cerebrospinal syphilis.

17. Southard and Solomon: Latent Neurosyphilis and the Question of General Paresis Sine Paresi, Boston M. \& S. J. 174:8, 1915. 
Multiple Sclerosis.-Recently, Moore ${ }^{18}$ has shown that a paretic curve is the usual reaction of the colloidal gold test in multiple sclerosis. He found that of twenty undoubted cases of multiple sclerosis, eighteen gave typical paretic curves. Among the cases of multiple sclerosis here there were five in which paretic curves were found. One of them has been confirmed by necropsy. This patient was admitted in 1913 with most of the characteristic symptoms of multiple sclerosis. She was later sent to another hospital, and there the same diagnosis was made. The patient died in January, 1920. At necropsy numerous areas of sclerosis were found in the cord and brain. These areas were distinct even macroscopically.

The spinal fluid findings were as follows: globulin, 2; albumin, 2 ; cells, 7 ; colloidal gold, 4444332000. The Wassermann reactions on the fluid and serum were twice negative.

TABLE 5.-Cerebrospinal Fluid Findings in Five Cases of MUltiple SClerosis

\begin{tabular}{|c|c|c|c|c|c|}
\hline Case & Globulin & Albumin & Cells & $\begin{array}{c}\text { Colloidal Gold } \\
\text { Curve }\end{array}$ & $\begin{array}{c}\text { Wassermann } \\
\text { Reaction }\end{array}$ \\
\hline $\begin{array}{r}5025 \\
6152 \\
\text { F. H. } \\
\text { B. C. } \\
\\
2223\end{array}$ & $\begin{array}{l}2 \\
3 \\
2 \\
2 \\
2 \\
3 \\
2 \\
2\end{array}$ & $\begin{array}{l}2 \\
3 \\
2 \\
2 \\
2 \\
2 \\
2 \\
2 \\
2\end{array}$ & $\begin{array}{r}43 \\
0 \\
2 \\
4 \\
8 \\
8 \\
14 \\
7\end{array}$ & 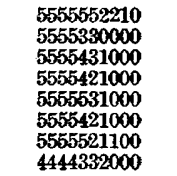 & $\begin{array}{l}\text { Negative } \\
\text { Negative } \\
\text { Negative } \\
\text { Negative } \\
\text { Negative } \\
\text { Negative } \\
\text { Negative } \\
\text { Negative }\end{array}$ \\
\hline
\end{tabular}

The blood Wassermann reaction was negative several times in each case.

Brain Tumors.-Brain and cord tumors generally give what is called a "chronic curve," $0011232110 .^{3}$ Many cases of brain tumor are to be found in state hospitals, but comparatively few such cases have been reported as giving paretic curves. Three cases with a diagnosis of brain tumor were found to have paretic readings in their spinal fluids, but only one of these could be definitely confirmed. This patient, whose spinal fluid gave a paretic curve on two different occasions, was found at operation to have a cerebellar tumor. The Wassermann reactions of the blood and spinal fluid were negative, and there was no evidence of syphilitic involvement of the central nervous system.

Larkin and Cornwall ${ }^{12}$ report a case of psammona of the dura with a gold reading of 552221000 . This is not a true brain tumor, and the reading is far removed from the typical paretic curve. Miller ${ }^{4}$ found a paretic curve in a case diagnosed as cerebral gumma. It is a question whether the new growth or the syphilis or a combination of both produced this reaction.

18. Moore: Cerebrospinal Fluid in Multiple Sclerosis, Arch. Int. Med. 25:58 (Jan.) 1920. 
Epidemic Encephalitis.-The reports of the colloidal gold findings in the present epidemic of encephalitis are not numerous. Almost all the cases at this hospital and most of the cases reported in the literature have given a syphilitic type of curve (1123321000). Barker ${ }^{19}$ and his associates in their review of epidemic encephalitis report one case showing a "combined paretic and meningitic curve," and another case with an "atypical paretic curve." One case of the choreiform type of lethargic encephalitis at this hospital gave a typical paretic curve in the first fluid obtained after admission. Two tests were made with two different colloidal gold solutions and a paretic curve resulted with each.

CASE 14272.-A man, aged 26, whose family history and early development apparently were normal, in the first part of 1918, had an attack of rheumatism lasting about two months. About ten days before admission to the hospital (April 21, 1920) the attack of encephalitis started with headache and pains all over the body. These pains were especially marked in the arms and back. After a few days choreic movements began, and the patient soon became delirious. Several times the patient saw double. Previous to the choreic movements the patient slept most of the time and it was difficult to arouse him. $\mathrm{He}$ was admitted to the hospital in a semidelirious condition. The choreic movements were marked and quite typical. The temperature was 103 and the pulse rate 104. The white blood cells numbered 16,000 .

Physical examination showed marked choreiform movements of the entire body. There was a faint systolic murmur at the mitral area. The deep reflexes were exaggerated, but no pathologic reflexes were present. The pupils were equal and regular and reacted equally well to light and accommodation. Otherwise the results of the physical and neurologic examinations were negative. Mentally, the patient remained in a semidelirious condition for a few days and then gradually the mental condition cleared up. The choreiform movements were checked by chloral. For about three weeks after the chloral was stopped, the patient was restless at night but would sleep almost all day, and it was difficult to arouse him. Fibrillary twitchings of the facial muscles were often noted. The temperature remained elevated for about a month. At the end of six weeks there was marked improvement and the patient had a fair insight into his condition.

The spinal fluid findings were: globulin, 2; albumin, 2; cells, 2 (small lymphocytes); colloidal gold, 5555542100 . Wassermann reactions of the spinal fluid and the blood were negative on two occasions.

This and similar cases are soon to be reported in greater detail.

Alcoholic and Drug Psychoses.-Among the cases with paretic curves in the spinal fluid appears one case of Korsakoff's psychosis (alcoholic). The diagnosis was confirmed by another hospital, and the patient was later discharged as improved.

19. Barker, Cross and Erwin: On Epidemicacite and Subacute Nonsuppurative Inflammations of the Nervous System, Prevalent in the United States in 1918 and 1919, Am. J. M. Sc. 159:157, 1920. 
CASE 5909.-A colored man, aged 38, whose family history and early development were normal and who had had no venereal history, had always been somewhat alcoholic, but this tendency had markedly increased during the year previous to admission. He is said to have been mentally well until about four or five days before admission when he began to complain of headache and pain in his neck. After a visit from a friend, he immediately went to the telephone to call up this friend, forgetting that he had just been there. The following day he was quite confused.

On admission to the hospital (Dec. 6, 1915) he was disoriented for time and place. He was confused, and his answers were more or less irrelevant. When asked to count backward from 20 to 1 , he had to give it up after trying for fifteen minutes and getting no further than 17. Memory for recent events was quite bad. He gave the ages of his three children as 2,3 and 8 months, respectively. No distinct fabrication was noted during his stay.

Physical examination showed a weakness of the muscles of the lower back and of the hamstring muscles, so that there was great difficulty in standing. The knee reflexes were unequal, that of the right knee being diminished. The pupils were normal, and there was no sensory disturbance.

The patient was soon transferred to another hospital from which he was discharged six months later with a final diagnosis of Korsakoff's psychosis.

The spinal fluid findings were: globulin, 1; albumin, 1; cells 2 (small lymphocytes); colloidal gold curve, 5553210000; Wassermann reactions of the blood and spinal fluid were twice negative.

In the literature many instances of colloidal gold tests in alcoholic psychoses are given, and some show mild changes in the gold, but no paretic curves are recorded.

The cerebrospinal fluid from a patient with drug (heroin) psychosis at this hospital in 1914 gave a paretic curve. This was complicated by the presence of a doubtful Wassermann reaction in both the spinal fluid and the blood. However, the patient was sent to another hospital and remained there until September, 1919, when she was discharged with a final diagnosis of drug addiction (not insane).

Lowrey ${ }^{5}$ reports a case of drug addiction with a colloidal gold curve reading 4444100000 , but there were positive Wassermann reactions in the serum and fluid. Moore ${ }^{18}$ states that a paretic curve is sometimes present in lead poisoning. No other gold reactions resembling a paretic curve could be found in many of the cases of drug addiction reported, although many did show mild changes in the syphilitic zone.

Undiagnosed Cases Definitely Not Paresis.-There were five other cases in which a definite diagnosis could not be made, but in which paresis could be ruled out.

CASE 4398.-The mother and several brothers of a white man, aged 40, died of tuberculosis. One sister was insane. The onset and course of the patient's illness was very indefinite. On admission (Feb. 21, 1915) he was found to be suffering from advanced pulmonary tuberculosis. There was involvement of the entire left lung and the upper and middle lobes of the 
right lung, with cavity formation. The neurologic examination was negative. The patient slept most of the time. Temperature, pulse and respirations were increased. Memory was poor for recent and remote events. His grasp on his surroundings was poor. No hallucinations or delusions were found. The patient was unemotional and had no insight. He gradually grew worse and died eleven days after admission. No signs of meningeal involvement were found at any time and a necropsy examination was not obtained; therefore the diagnosis of tuberculous meningitis, which is the most probable one, could not be confirmed. A guinea-pig was inoculated, but owing to contamination no results were obtained.

The spinal fluid findings were: globulin, 3; albumin, 4; cells, 69 (small lymphocytes. 68 per cent., large lymphocytes, 22 per cent., plasma, 3 per cent., polymorphonuclears, 7 per cent.). The colloidal gold curve was 5555554321 . The Wassermann reactions in the fluid and serum were twice negative.

Cases of tuberculous meningitis with paretic curves have been reported as shown in Table 6.

CASE 13364.-A white woman, aged 49, whose family history was negative, was healthy until 12 years old when she developed curvature of the spine; since then she has worn braces occasionally. The patient graduated from normal school when she was 21 and was considered a good student. She was somewhat of a "book worm." When about 28 years old she began to prepare to get married. She had a wedding dress made and even resigned her posisition, but there was no man in the case. The patient was at that time sent to a state hospital and remained there two months. She has not been normal since, according to her friends. She has a circle of friends whom she calls her "arch friends" and who have a "program" of persecution. After making several attempts to kill one of them she was sent to this hospital for observation (Oct. 14, 1919).

On admission her mental condition showed nothing abnormal except a wealth of paranoid ideas that she had maintained for twenty years. Among her "arch friends" was a man or male spirit whom she prepared to marry twenty years ago. Since then this spirit has had sexual intercourse with her by means of electricity. The patient had a religion all her own in which her hands play an important part. Auditory and visual hallucinations were denied. She had some insight at times. Personality was well retained.

Physical examination revealed a right upper thoracic scoliosis and a resulting deformity of the chest. There was a scar on her right breast where the entire right mammary gland was removed a few weeks before entering this hospital. There was a lump the size of a walnut in the left breast and palpable axillary glands. The neurologic examination was negative.

After four months the patient was transferred to another hospital from which she was later discharged as improved. The diagnosis remained "paranoid condition."

The spinal fluid findings were: globulin, 1; albumin, negative (?) ; cells, 3 small lymphocytes, 1 large lymphocyte; colloidal gold curve, 5555531000 (two tests). The Wassermann reactions on the spinal fluid and serum were twice negative.

CASE 13179.-A white man, aged 26 (?), whose family history was somewhat defective, was a full term, healthy baby but could not talk until he was 4 years old. He had smoked excessively since he was 8 years old. He was quarrelsome and mischievous as a child, but quite honest. He was backward 
in school and did not learn to read very well. He repeated the fourth and fifth grades and never got much further. At 13 he ran away from school. In 1914 he was arrested for stealing and sent to this hospital. Because of an apparent character change and abnormal emotional reaction the condition was diagnosed as dementia praecox simplex, and the patient was transferred to another hospital. After three months there he was discharged and went back to work as a machinist. His mental age at that time was 11.1. In 1917 he enlisted and was sent to France. He was returned to this country in January, 1919, after being gassed twice, and was placed at various base hospitals. Finally, he remained away without official leave for eleven days and was sentenced to serve three years. After serving four months he was again sent to this hospital for observation.

On admission (Sept. 8, 1919) he was correctly oriented. Memory was somewhat bad and the details of his story did not check up well. Calculation ability and school knowledge were rather poor. No evidence of delusions was found, but he admitted hearing bells and voices while in France. Emotional responses were quite normal, and personality was well retained. There was no disturbance of thought processes. His mental age was not tested again. Physically, he was well developed and well nourished. His breath was foul, and the tongue was tremulous, rough and fissured. His hands and feet were cold and cyanotic. The pupils were irregular and reacted sluggishly to light and accommodation through a narrow arc. The knee reflexes were sluggish but equal. Sensation was normal. There was no Romberg sign.

The spinal fluid findings were: globulin, 1; albumin, 1; cells, 41 small lymphocytes; colloidal gold curve, 5554432100. The colloidal gold test was repeated with a different colloidal gold solution, and practically the same result was obtained. The Wassermann reactions on the serum and spinal fluid were consistently negative several times. The patient was given provocative arsphenamin, but the Wassermann test remained negative. After the provocative treatment another lumbar puncture was made with the following results: globulin, 1; albumin, 1; cells, 20 small lymphocytes; colloidal gold curve, 0123220000 .

Since being discharged the patient has gone back into the transport service and is getting along well. The blood Wassermann test remains negative.

CASE 13430.-The patient gave a history of excessive alcoholism for several years before admission to the hospital with an increase in the amount of alcohol consumed just prior to entrance. A history of a chancre about a year and a half before admission complicated the case. The patient became hallucinated about six months before he was sent to the hospital. On entrance he had marked hallucinations and delusions. The hallucinations were auditory and were mostly in the third person. He thought that he was persecuted by the Catholics and that they had electromagnets which controlled his thoughts. There were numerous other delusions of persecution. There was no obvious disintegration of personality and no memory loss. The patient was superior in the psychometric test. Orientation was intact, and there was no disorder of consciousness. Emotional tone was in keeping with his delusions. The physical and neurologic examinations were entirely negative. After six weeks in the hospital the hallucinations had almost completely disappeared, and the patient had good insight.

The spinal fluid findings in the first fluid tested were: globulin, 1; albumin, 1 ; cells, 8 small lymphocytes; colloidal gold curve, 5555321000. The Wassermann test was negative. The patient was given several intravenous injections 
of arsphenamin, but the blood and spinal fluid Wassermann reactions remained negative, while the other spinal fluid tests were practically the same on two subsequent examinations.

CASE 5364.-A girl, aged 23, admitted to this hospital in 1915, was of the defective delinquent type, and this was the provisional diagnosis, although her case was later left unclassified. She was moody, depressed and easily irritated. She had delusions of persecution, but no hallucinations. Physical examination revealed only poorly reacting pupils. The diagnosis of manic depressive insanity was considered, and it is possible that it was a case of neurosyphilis although the Wassermann reaction was negative. The patient was sent to another hospital from which she was later discharged as improved.

The spinal fluid findings were: globulin, 2; albumin, 2; cells, 13 ; colloidal gold curve, 5555543310 . The Wassermann test was negative.

TABle 6.-Miscellaneous Cases; Neurosyphilis and Multiple SCLERosis EXCLUded

\begin{tabular}{|c|c|c|c|c|}
\hline Author & $\begin{array}{l}\text { Number } \\
\text { of Cases }\end{array}$ & $\begin{array}{c}\text { Source or Type } \\
\text { of Cases }\end{array}$ & $\begin{array}{l}\text { Paretic } \\
\text { Curves }\end{array}$ & Conditions \\
\hline 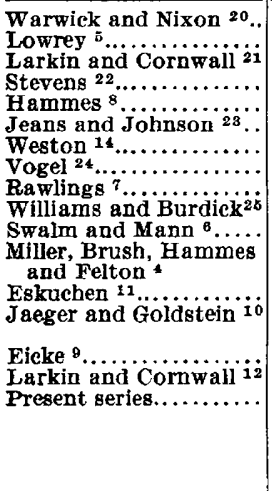 & $\begin{array}{r}245 \\
115 \\
114 \\
38 \\
92 \\
100 \\
165 \\
52 \\
319 \\
79 \\
27 \\
102 \\
56 \\
54 \\
222 \\
115 \\
6,500\end{array}$ & 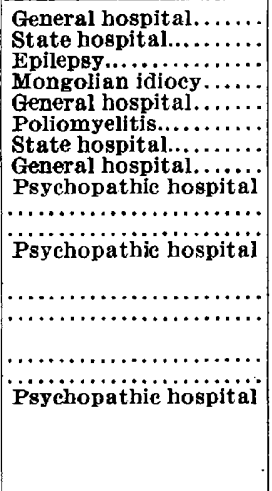 & $\begin{array}{l}1 \\
1 \\
1 \\
1 \\
0 \\
0 \\
0 \\
2 \\
1 \\
1 \\
0 \\
0 \\
2 \\
0 \\
3 \\
0 \\
4 \\
9\end{array}$ & $\begin{array}{l}\text { Undiagnosed } \\
\text { Questionsble } \\
\text { Defective } \\
\text { Brain abscess; tuberculous } \\
\text { meningitis } \\
\text { Brain abscess; tuberculous } \\
\text { meningitis; epilepsy } \\
\text { Eelampsia, 2; psammoma of } \\
\text { Cerebellar tumor, 1;. Korsa- } \\
\text { koff's psychosis, 1; encephs- } \\
\text { litis, 1; drug addict, 1; tu- } \\
\text { bereulous meningitis, (?) } 1 \text {; } \\
\text { undiagnosed, } 4\end{array}$ \\
\hline
\end{tabular}

20. Warwick and Nixon (Footnote 2).

21. Larkin and Cornwall: Spinal Fluid in Epilepsy, J. Lab. \& Clin. Med. 4:352, 1919.

22. Stevens, H. C.: The Spinal Fluid in Mongolian Idiocy, J. A. M. A. 66: 1373 (April 29) 1916.

23. Jeans and Johnston: Am. J. Dis. Child. 13:329, 1917.

24. Vogel, K. M.: The Nature and Interpretation of the Colloidal Gold Reaction, Arch. Int. Med. 22:496 (Oct.) 1918.

25. Williams and Burdick: Lange Colloidal Gold Reaction, Colorado Medicine 13:103, 1915.

Rawlings ${ }^{7}$ reports a case with a paretic curve in which the diagnosis was "defective."

In the literature from other similar hospitals, from general hospitals and from army hospitals, other conditions giving rise to paretic curves were found. These, together with the cases from this hospital, are given in Table 6, which gives the miscellaneous cases reported, 
excluding neurosyphilis and multiple sclerosis, because paretic curves are to be expected in such cases.

\section{VARIOUS OTHER CONSIDERATIONS}

Relation to Other Tests.-The nonconcomitance of spinal fluid tests has been fully discussed by Solomon. ${ }^{26} \mathrm{He}$ concludes that any one of the usual five tests may be present or absent when the others are present, because each reaction is produced by a distinct chemical element that may be present alone. The relation to the Wassermann test is shown in Table 3 and has been discussed by Hammes. ${ }^{8}$

Effects of Treatment.-The colloidal gold reaction may vary considerably under treatment just as the other spinal fluid and blood tests do. With intensive treatment in favorable cases the tendency is for the paretic curve to become irregular or change to the "syphilitic type" and then finally to become negative. We have many such instances of which the following is a good example:

Table 7.-Variation of Colloidal Gold Reaction Under Treatment*

\begin{tabular}{|c|c|c|c|c|c|c|}
\hline \multirow{2}{*}{ Date } & \multirow{2}{*}{$\begin{array}{c}\text { Colloidal Gold } \\
\text { Curve }\end{array}$} & \multirow{2}{*}{$\begin{array}{l}\text { Glob- } \\
\text { ulin }\end{array}$} & \multirow{2}{*}{$\underset{\text { min }}{\text { Albu+ }}$} & \multirow{2}{*}{ Cells } & \multicolumn{2}{|c|}{ Wassermann Reaction } \\
\hline & & & & & $\begin{array}{c}\text { Cerebrospinal } \\
\text { Fluid }\end{array}$ & Serum \\
\hline $\begin{array}{r}3 / 21 / 15 \\
3 / 31 / 15 \\
4 / 7 / 15 \\
5 / 8 / 15 \\
8 / 13 / 15 \\
10 / 21 / 15\end{array}$ & $\begin{array}{l}5555554321 \\
5555553100 \\
5555543200 \\
0011100000 \\
1000000000 \\
0000000000\end{array}$ & $\begin{array}{l}4 \\
4 \\
3 \\
2 \\
1 \\
0\end{array}$ & \begin{tabular}{c|}
4 \\
4 \\
3 \\
1 \\
1 \\
Normal
\end{tabular} & $\begin{array}{r}80 \\
96 \\
67 \\
8 \\
5 \\
4\end{array}$ & $\begin{array}{l}\text { Positive } \\
\text { Positive } \\
\text { Positive } \\
\text { Doubtful } \\
\text { Negative } \\
\text { Negative }\end{array}$ & $\begin{array}{l}\text { Positive } \\
\text { Doubtful } \\
\text { Doubtful } \\
\text { Doubtful } \\
\text { Negative } \\
\text { Negative }\end{array}$ \\
\hline
\end{tabular}

* Intensive intraspinal and intravenous treatment.

The time of disappearance of the paretic curve is variable as has been pointed out by Solomon. ${ }^{26}$ According to Neyman and Frush, ${ }^{27}$ the paretic curve is the last of the positive spinal fluid reactions, with the exception of the globulin test, to disappear under treatment.

Improvement in the paretic curve is not the rule in treated cases. In fact, the reaction may become more pronounced either temporarily or permanently, just as the Wassermann reaction has been observed to do. The changes in the colloidal gold test may not parallel the clinical change in a treated patient. At present the paretic curve, as well as the other reactions of a patient who is having an almost perfect clinical remission, remain strongly positive in spite of intensive treatment. The opposite condition has also been found in a few instances. However, when there is clinical improvement and the other tests tend

26. Solomon, H. C.: Nonconcomitance of Spinal Fluid Tests, Arch. Neurol. \& Psychiat. 3:49 (Jan.) 1920.

27. Neymann and Brush: Treatment of General Paralysis, Arch. Int. Med. 22:245, 1918. 
to clear up, the gold reaction will, in the great majority of cases, follow the same course.

Provocative Colloidal Gold Test.-McBride ${ }^{16}$ made the statement that there is no colloidal gold reaction to provocative treatment but, on the other hand, Warwick and Nixon ${ }^{20}$ and others speak of finding a provocative colloidal gold reaction. We have several cases in which the colloidal gold reaction was at first negative, but after a few treatments, a typical paretic curve appeared and remained for some time. This has happened too often to be merely coincidental. The cases in Table 8 are illustrative of this, and it will be noted that the other findings may also become more marked.

Table 8.-Colloibal Gold Reactions to Provocative Treatment

\begin{tabular}{|c|c|c|c|c|c|c|c|}
\hline \multirow[b]{2}{*}{ Date } & \multirow{2}{*}{$\begin{array}{l}\text { Colloidal } \\
\text { Gold Curve }\end{array}$} & \multirow{2}{*}{$\begin{array}{l}\text { Glob- } \\
\text { ulin }\end{array}$} & \multirow{2}{*}{$\begin{array}{l}\text { Albu- : } \\
\text { min }\end{array}$} & \multirow{2}{*}{ Cells } & \multicolumn{2}{|c|}{ Wassermann Reuctions } & \multirow[b]{2}{*}{ 'I'reatment } \\
\hline & & & & & $\begin{array}{l}\text { Cerebro- } \\
\text { spinal } \\
\text { Fluid }\end{array}$ & Serum & \\
\hline $\begin{array}{l}\text { Case } 13013 \\
1 / 24 / 19\end{array}$ & 0011230000 & $\dddot{?}$ & $\dddot{y}$ & $\dddot{139}$ & Negative & Positive & \multirow{2}{*}{$\begin{array}{l}\text { Between dates given, } 33 \\
\text { intravenous injections } \\
\text { and } 7 \text { grains of mer- } \\
\text { cury; no previous } \\
\text { treatment }\end{array}$} \\
\hline $10 / 4 ! 19$ & 5444310000 & 1 & 1 & 30 & $5 \bar{x}(\operatorname{coc} 0$ & Negative & \\
\hline $\begin{array}{c}\text { Case C. A. } \\
1 / 15 / 19\end{array}$ & 0000000000 & $\dddot{0}$ & $\dddot{\mathrm{N}}$ & $\ddot{\underline{\prime}}$ & Pcsitive & „ c c sitive & \multirow{2}{*}{$\begin{array}{l}\text { No previous treatment: } \\
\text { between dates given } 19 \\
\text { intravenous injections } \\
\text { and } 11 \text { grains of mer- } \\
\text { cury }\end{array}$} \\
\hline $1 / 20 / 20$ & 5555531000 & 1 & 2 & 2 & 555500 & Positive & \\
\hline $\begin{array}{c}\text { Case W. F. } \\
11 / 18 / 15\end{array}$ & 1233330000 & 3 & 3 & 20 & 55520 & Negative & \multirow{4}{*}{$\begin{array}{l}3.3 \mathrm{gm} . \text { arsphenamin } \\
2.2 \mathrm{gm} . \text { arsphenamin } \\
1.8 \mathrm{gm} . \text { arsphenamin }\end{array}$} \\
\hline $12 / 15 / 15$ & 5555553100 & 3 & 2 & 12 & 50420 & Ioubtful & \\
\hline $2 / 24 / 16$ & 3333220000 & 2 & 2 & 2 & Doubtful & Negative & \\
\hline $1 / 26 / 17$ & 0000000000 & 1 & 1 & 2 & 53111 & Negative & \\
\hline$\underset{6 / 14 / 19}{\text { Case W.Mc. }}$ & 0000001010 & $\dddot{0}$ & $\dddot{\mathbf{N}}$ & $\dddot{0}$ & Negative & ritgative & \multirow{3}{*}{$\begin{array}{l}\text { No previous treatment } \\
1.6 \mathrm{gm} \text {. arsphenamin } \\
1.3 \mathrm{gm} \text {. arsphenamin }\end{array}$} \\
\hline $8 / 2 / 19$ & 5555431000 & 1 & 1 & 13 & Negative & Negative & \\
\hline $\begin{array}{r}9 / 6 / 19 \\
10 / 11 / 19\end{array}$ & $\begin{array}{l}5444321000 \\
5433211000\end{array}$ & $\begin{array}{l}1 \\
1\end{array}$ & $\begin{array}{l}1 \\
1\end{array}$ & $\overline{1}$ & $\begin{array}{l}\text { Negatire } \\
\text { Negatjve }\end{array}$ & $\begin{array}{l}\text { Negative } \\
\text { Negative }\end{array}$ & \\
\hline 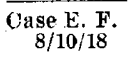 & $\begin{array}{l}1112321000 \\
1114321000\end{array}$ & 2 & 2 & 116 & 500000 & Positive & \multirow{3}{*}{$\begin{array}{l}0.8 \mathrm{gm} \text {. arsphenamir } \\
\text { and 1 intraspinal in } \\
\text { jection: } 4 \text { gm. ars } \\
\text { phenamin }\end{array}$} \\
\hline $12 / 2 / 18$ & 5554443221 & 1 & 1 & 3 & 555540 & Positive & \\
\hline $11 / 2 / 19$ & 55554443210 & 1 & 1 & 3 & 555550 & Negative & \\
\hline $\begin{array}{c}\text { ('ase } \mathbf{F} \text { M. } \\
5 / 15 / 18\end{array}$ & 0001332110 & $\underline{1}$ & 1 & 56 & .......... & Doubaful & \multirow{4}{*}{$\begin{array}{l}8.4 \mathrm{gm} . \text { arsplienamin } \\
2.3 \mathrm{gm} \text {. arsphenamin } \\
2.6 \mathrm{gm} . \text { arsphenamin }\end{array}$} \\
\hline$: 3 / 15 / 19$ & 1222333310 & 0 & $\mathbf{N}$ & $\cong$ & 5000000 & Negutive & \\
\hline $8: 9: 19$ & 5433310000 & 0 & 1 & $i$ & 2200000 & Negative & \\
\hline $1 / 24 / 20$ & 0111110100 & 1 & 1 & 5 & Negative & Nogative & \\
\hline
\end{tabular}

It sometimes happens that without the usual treatment a paretic curve may appear after three or four lumbar punctures. This may in some cases be coincidental with the development of the disease, or it may be that the repeated lumbar punctures act as a provocation. 
Effect of Contamination.-Varions contaminations of the cerebrospinal fluid may modify the paretic curve. The fluid may become contaminated by using dirty test tubes or old corks that have been used with drugs; by the growth of -yeasts or molds; by blood obtained when the limbar puncture is made; and by various other foreign substances. In general, such contaminations may change a syphilitic type of fluid into a paretic type, but will seldom if ever produce a paretic curve in an absolutely normal fluid. A paretic fluid that has become contaminated will usually give a somewhat irregular reading resembling a paretic curve and may become practically negative.

With due care all these sources of contamination may be avoided with the exception of blood, which will sometimes be obtained in spite of all precautions. After repeated experiments of adding various quantities of blood to known normal fluids, it was found impossible to produce a reading that could be called a paretic curve. Such fluids would show marked and irregular color changes in the middle or at the end of higher dilutions. Addition of blood to the syphilitic type of fluid would occasionally give a paretic curve. Blood added to a known paretic fluid would generally produce an irregular reading but not a negative one. However, in cases contaminated at the time of puncture, paretic curves have been noted in normal cases and vice versa.

The effects of the presence of blood in the cerebrospinal fluid has been discussed by Black ${ }^{16}$ and Kellert. ${ }^{28}$

\section{CONCLUSIONS}

1. The paretic gold curve does not always indicate paresis, but, if used in conjunction with the other spinal fluid tests, it is a most valuable test for this disease. In some instances, this reaction is the deciding factor in the diagnosis of general paralysis.

2. The vast majority of cases of paresis will give a paretic type of gold reaction. In a case that does not give such a reaction after more than one examination, the diagnosis of paresis is always questionable.

3. The presence of paretic curves in almost 50 per cent. of the cases of cerebrospinal syphilis shows that a paretic curve does not serve to differentiate paresis from this condition. However, the absence of a typical reading points strongly to cerebrospinal syphilis when the differential diagnosis lies between these two conditions.

4. A paretic or marked syphilitic curve is to be expected in multiple sclerosis.

28. Kellert: Observations on Colloidal Gold Reactions with Cerebrospinal Fluid, Am. J. M. Sc. 159:257, 1920. 
5. Besides paresis and multiple sclerosis, a paretic curve is occasionally found in the following conditions: tabes dorsalis, cerebrospinal syphilis, undifferentiated neurosyphilis, brain tumor, brain abscess, encephalitis, tuberculous, meningitis, Korsakoff's psychosis (alcoholic), eclampsia, epilepsy, lead poisoning (?) and drug addiction (?).

6. The pathology of the above conditions would indicate more or less destruction of nerve cells in the brain, or, in other words, a parenchymatous involvement. It may be concluded, therefore, that a paretic curve points toward parenchymatous involvement of the brain, while the milder gold curves are obtained in meningitis, vascular disease and other conditions. The paretic curve is not only of diagnostic value, but also of prognostic value. 